\title{
Intensification of Competition in European and Global Higher Education: The Role of Globalisation and Transaction Costs
}

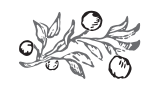

Summary

The topic of this study is the intensification of competition in different dimensions of higher education in the European and global space. This is examined in light of globalisation and the concomitant reduction in transaction costs. Changes in transaction costs, European regional integration and the impact of globalisation are discussed in a broader sense, and within the scope of higher education. It is argued that reduction in the transaction costs is both a driving force and a consequence of regional integration and globalisation in higher education, and more specifically, it forces both national higher educational systems and individual higher education institutions into a very sharp system of regional and global interdependence. The challenges faced by less developed regions of the European Union, i.e. the southern and central European peripheries, and the opportunities offered in the European integration processes, have been highlighted and the emphasize is drawn upon them.

Journal of Economic Literature (JEL) codes: I21, F60, D23

Keywords: European Higher Education Area, higher education, globalisation, regional integration, transaction cost

József Golovics PhD, Assistant Professor, Corvinus University of Budapest (jozsef.golovics@uni-corvinus.hu); PÁl Veres PhD, Rt. Associate Professor, Corvinus University of Budapest (pal.veres@uni-corvinus.hu). 
Civic Review · Vol. 16, Special Issue, 2020

\section{INTRODUCTION}

Education is a sector of national strategic importance. However, this does not mean that the various issues of the educational system can be interpreted exclusively in the context of nation-states. Although national governments are responsible for shaping educational policy, and the educational institutions are mostly maintained and funded by (local or central) government bodies, international actors also have a significant influence on the processes that take place in the educational system.

Education, and in particular, European higher education, is increasingly internationalised, and today national higher educational systems may only be interpreted in the European regional and global space. Note, for example, the international flow of teachers, students and knowledge, co-operation between higher education institutions (HEI), the establishment of frameworks to assist them and improve their transparency, the feed-through of global economic effects, the "following" of foreign patterns (Veres, 2010) or even the emigration of highly qualified people, called brain drain (Golovics, 2019a). Thus, higher education and its stakeholders are affected by external influences at the level of the nation-state, the system, the organisation and even the individual, and the interdependence between regions and the global space is intensifying. The "technical and institutional" basis of this growing interdependence is the dismantling of the barriers to factor flows, interactions and transactions, and the resulting increase in competition.

This study focuses on the integration of national higher educational systems into the European Higher Education Area (EHEA), the specific institutional environment of the European Union (EU) and its consequences, and thus ultimately on the link between higher education and globalisation. (The evolution of the EHEA and the EU is considered as part of the wider globalisation process, or its regional manifestation, and a specific institutional degree.) Globalisation is, of course, a very complex process in itself, and one of its essential elements is the expansion of interdependence (Szentes, 2002). As Székely-Doby puts it, the simplest way to define globalisation is to view it as "the increasing integration and unification of markets" (Székely-Dobi, 2007, p. 287). In our opinion, the important driving force and consequence of this integration and unification is decrease in the transaction costs (although in some cases, one may undoubtedly face increase).

Certain aspects of the multifaceted relationship between globalisation and higher education have already been explored. Deli-Gray et al. (2010) and Vaira (2004) focus on the effects of globalisation on the organisational functioning and marketing strategy of HEIs, Rohonczi (2012) reviewed the issues of higher educational competitiveness in the process of globalisation, and Gervai and Trautmann (2014) discuss the change and transfer of values for the two factors. This study focuses on the consequences of declining transaction costs, the different aspects of competition that will intensify as a result, and the challenges and opportunities national systems will face.

According to Furubotn and Richter, "transaction costs" are "the costs of running an economic system or a social system" (Furubotn and Richter, 2005, p. 568). As Wil- 
József Golovics, Pál Veres: Intensification of Competition in European and Global...

liamson (1985) puts it, they bring a kind of "friction" into the system of social interactions. In this study, however, it is argued that in the process of globalisation, these frictional costs are mostly reduced, and this has a significant impact on the functioning of national higher education systems and the behaviour of stakeholders.

The manifestations of this reduction in transaction costs are assessed through technological development and globalisation and regional integration processes, and then the contribution of these trends to the intensification of competition between higher education stakeholders is discussed in a European and global perspective.

\section{DEGREASE IN TRANSAGTION COSTS}

\section{Technological changes and cultural convergence}

One of the most important drivers of globalisation is the revolution and the uninterrupted rapid development of info-communication technology (ICT). In addition to placing production and services on a new footing, ICT development has, in many cases, also helped organise them, by facilitating interaction (communication and transaction). Although it is a complex process with manifold effects, there is general consensus that ICT development has reduced the transaction costs of economic and social operations (Hámori, 2013).

While ICT allows fast and easy communication between the most remote parts of the Earth without travelling, the cost of international mobility has also drastically reduced as a result of development in global transport and freight networks. The latter constitute transaction costs when someone works or studies abroad: note the direct costs of transport or travel (e.g. ticket prices) and the opportunity costs (e.g. travel time), but actually all activities related to its organisation (orientation, search, comparison and communication) have also become easier (Hummels, 2007). ${ }^{1}$

An important element in the process of globalisation is the convergence of cultures, which also contributes to the facilitation of international communication and thus co-operation, including the expansion of foreign language skills and the emergence of English as a global language (Crystal, 2012). This is well illustrated by the fact that in 2017, English was compulsory in almost 95 per cent of upper secondary schools in EU Member States (excluding the UK, Eurostat, 2019a), and 64.6 per cent of the population aged 25-64 claimed to speak at least one foreign language (Eurostat, 2019b). These also contribute to the reduction of transaction costs.

\section{Institutions in the regional and global space}

According to North (1990), one of the basic functions of institutions is to reduce transaction costs. The development of the mentioned supra-national institutions in the social, political and business sectors should be considered in the context of globalisation and, more specifically, of regional integration processes (Gilpin, 2001). At times they result in the emergence of new structures, while at other times the disman- 
tling of the existing barriers, and their aim, in North's understanding, is to facilitate the free flow of the factors of production and to make transactions more frictionless.

Our continent is at the forefront of regional integration efforts. The EU's fundamental achievements include guaranteed free movement of goods, services, capital and people, which, as detailed in the next chapter, also have obvious consequences for the stakeholders of higher education.

The foundations of targeted integration in higher education and the creation of regional institutional structures, such as the EHEA were laid by the Sorbonne Declaration (1998) and the Bologna Declaration (1999). The aim of the establishing the EHEA was to create an easily comparable training system, i.e. a system with low transaction costs. Promoting mobility was among the set goals, and the means to achieve it included, among other things, multi-cycle training, the credit system and the development of other comparable quality assurance, evaluation and certification criteria. Although the resulting structure, called the Bologna Process and the Bologna Training System, and its national implementations (which are far from complete uniformity) have been widely criticised in recent decades (Hrubos, 2018), and there is no doubt that the mostly unified (institutional) foundations make a significant contribution to reducing transaction costs for higher education stakeholders.

In addition to EHEA, numerous other initiatives have been made by both governmental and non-governmental actors to reduce transaction costs in higher education by creating a certain kind of institutional structure. These include the European Qualifications Framework (EQF) for lifelong learning or the International Standard Classification of Education (ISCED). The EQF is essentially an output of the national educational system (based on learning outcomes), a tool for comparing and matching qualifications, and an system of information to help the stakeholders in education make educational and employment-related decisions. The EQF defines 8 levels of output (4 of which essentially belong to higher education) and at each level it determines learning outcomes in terms of knowledge, skills, responsibility and autonomy. National qualifications frameworks are free to determine the number of qualification (output) levels, but are aligned with the EQF in that they are based on learning outcomes. ${ }^{2}$ For each country, the conformity of each national level to a specific EQF level was determined in an EU procedure. Through the latter as an intermediary tool, the output levels of the countries have become comparative, and thus significant information (transaction) costs are saved in mobility for studies or work purposes. Joint training by institutions from different countries and building cascaded training levels for learning mobility, both supported by the EQF and national frameworks, further reduced transaction costs.

Qualifications frameworks also serve as frameworks for lifelong learning. The overlapping levels of training and output also serve as a cost-saving tool for a lifelong "construction" at the level of the individual. The purpose of adult learning may be, for example, to "update" knowledge corresponding to a certain level or to raise the level of qualification, i.e. obtain a new qualification, which entails significant cost savings through crediting prior studies (Veres, 2015). The above applies in both the regional and the global space for both horizontal and vertical "mobility". ${ }^{3}$ 
József Golovics, Pál Veres: Intensification of Competition in European and Global...

In addition to frameworks, higher education rankings also help to improve comparability. Although extremely different in terms of focus, data use, and measurement methods (Temesi, 2011), they have the fundamentally common goal of measuring performance and ranking higher education systems or their institutions according to some system of indicators. Just as each higher education institution sees different things as its primary task and specialise in different activities, various rankings also prioritise different indicators, and so they are most useful when comparing institutions within the same "category" and trends over time. Although rankings are regularly criticised (Hrubos, 2014), they also provide important information for consumers (potential students, employers), supply-side actors (institutions, their employees, owners) and the government, which is responsible for shaping education policy. In doing so, they facilitate orientation and consequently reduce transaction costs, while also influencing the co-operating and competitive international environment.

Based on all this, the process of globalisation clearly comprises a number of phenomena that reduce transaction costs in themselves. However, they also have an impact on relationships and interactions between the actors.

\section{INTENSIFICATION IN COMPETITION IN THE EUROPEAN AND GLOBAL AREA}

Stakeholders in higher education systems, being natural persons (students, teachers, etc.) or organisations (training institutions, employers, government bodies, etc.), interact with each other in the same way as other actors in the social and economic life: they compete or transact. Their transactions primarily include interactions and exchanges between HEIs, between institutions and students, and between institutions and employers. However, it is also clear that due to the large number of actors there may be competition between the parties on both sides of the transactions. A significant part of the competitive situation has now moved to a much wider, European and even global space, and has become "friction-free" and thus relatively cheaper in terms of benefits through the above-described transaction cost reduction processes. This, in turn, attracts more players to the globalising transaction space, and generates sharper competition in every respect between players on the same side of the transactions.

Although, this study basically focuses on stakeholder competition, it is emphasised that co-operation is at least as important in the functioning of a market economy. Not the least because at the end of the day the competitive situations end in co-operation between the HEI and the admitted student, or the employer and the graduate, but previously competing candidates may also co-operate as university students during their studies and after graduation, or even work in a joint team at the same workplace. Note that the other processes of globalisation have also significantly reduced transaction costs at these points of co-operation. To put it simply, in addition to competition, co-operation has also become more frictionless and profit is cheaper to make. As a result, significant co-operation networks have developed in international higher education (e.g. global inter-institutional research collaborations and networks of stu- 
Civic Review · Vol. 16, Special Issue, 2020

dent organisations), but the increasing number of participants attracted also intensify competition.

\section{Competition between candidates}

As a result of the factors ${ }^{4}$ presented above, studies abroad have become an increasing reality globally in recent decades at all levels of education. The competition for better places, including training for institutions with higher prestige and quality education, is thus already taking place across nation-state borders. As a result of reduced transaction costs, students face far more competitors at the gates to the desired institution. Thus, it is no longer enough for the "best" of a country to be the best in their home country, as the "best" of other states may appear on the former, quasi-competition less field. However, they can also enter the - international arena, where they may even face the fact that they are no longer necessarily among the "best" any more. Of course, this may have also serve as an incentive to harder work in studies as a positive outcome, but it can also lead to exclusion from higher education. The probability of the latter can be substantially reduced by the fact that supply for the current demand can now be provided in a wider, international space with lower transaction costs.

However, international competition is not only for better institutions, but also for a more favourable form of funding. For the vast majority of applicants, not only transaction costs but also training and living costs matter. For this reason, it may be important that these burdens may be borne in part or full by another actor (the HEI, a local or central government, or another organisation). ${ }^{5}$ The most important question in this competition is the criteria and conditions for an applicant to win the best form of funding. In an international context, special attention should be paid to the regulatory approach to foreign applicants. In the EU, the nationals of Member States can participate in higher education in any other Member State under the same conditions as the nationals of the host country, and thus the opportunities for applicants increase exponentially if transaction and training costs are affordable or a sufficiently favourable form of funding is provided (but the same conditions do not apply to social benefits on a mandatory basis).

A large proportion of students in higher education in the EU Member States - almost 10 per cent on average at an EU level - come from abroad.

\section{Competition between HEIs}

HEIs also have an interest in having the best students "within their walls". There are both professional (higher educational standards, better professional results and higher prestige, etc.) and financial reasons (tuition fees and external per capita funding sources). Universities can now compete at lower transaction costs than before. Under these circumstances, universities that can offer a significant number of scholarships are able to attract the best students. This capacity of universities can be improved through tuition, state support and other resources. 
József Golovics, Pál Veres: Intensification of Competition in European and Global...

Figure 1: Foreign students in higher education in EU Member States (2017, \%)

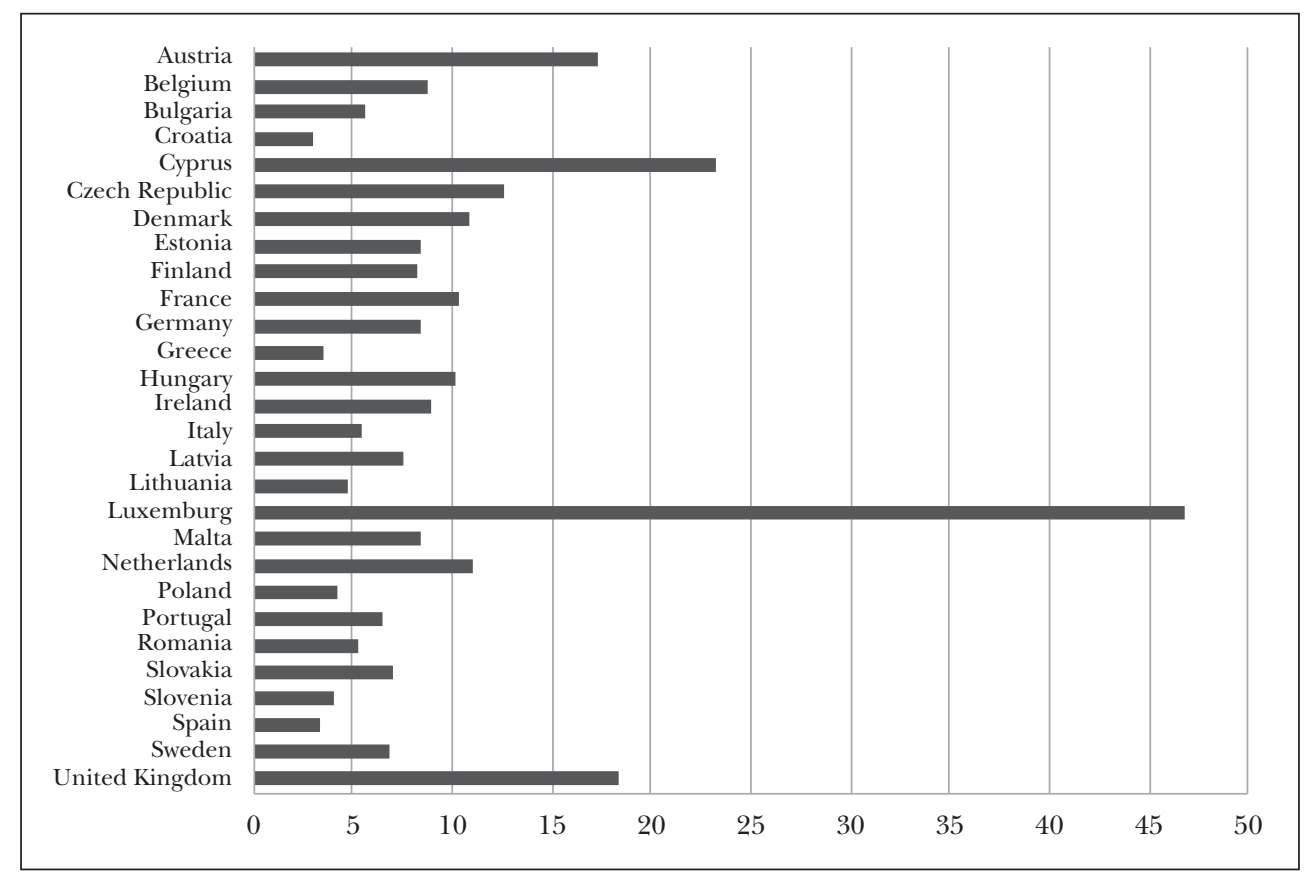

Source: Eurostat, $2020 a$

HEIs are also in fierce competition for different sources, and to a large extent, they are now doing so internationally. On the one hand, funding can come from the admitted students in the form of tuition fees or third-party funding (per capita public funding or tuition transfer, etc.), however, depending on the profile, access to research resources may also be essential for a significant number of universities. These may come from the government or from non-profit and corporate sectors, and the race for them is also international. In an EU context, we can think of research project resources co-funded with the European Social Fund, or Horizon 2020, which provided around EUR 80 billion for various innovation and research purposes between 2014 and 2020. The highest number of applications was submitted by HEIs (European Commission, 2020). Figure 2 shows that the ratio of countries in the catching-up phase is marginal in terms of the aid awarded.

In addition, HEIs also compete in the regional and global space for employees (lecturers, researchers and other staff) with the highest levels of competencies relevant to their mission. In addition to their institutional characteristics, competitiveness, taken in this perspective, is also significantly affected by the wage level in their country. The assumption of payables by other actors (local and central government, other organisations, or a community) may be important in funding wages and other special cost surpluses. However, overall, the current trends in globalisation have also led to increased competition in this area, including the issue of the "visibility" of a good workforce, the 
Civic Review · Vol. 16, Special Issue, 2020

Figure 2: Financial contribution by the EU to participants in grant agreements: Horizon 2020 to $\mathrm{FP}^{6}$

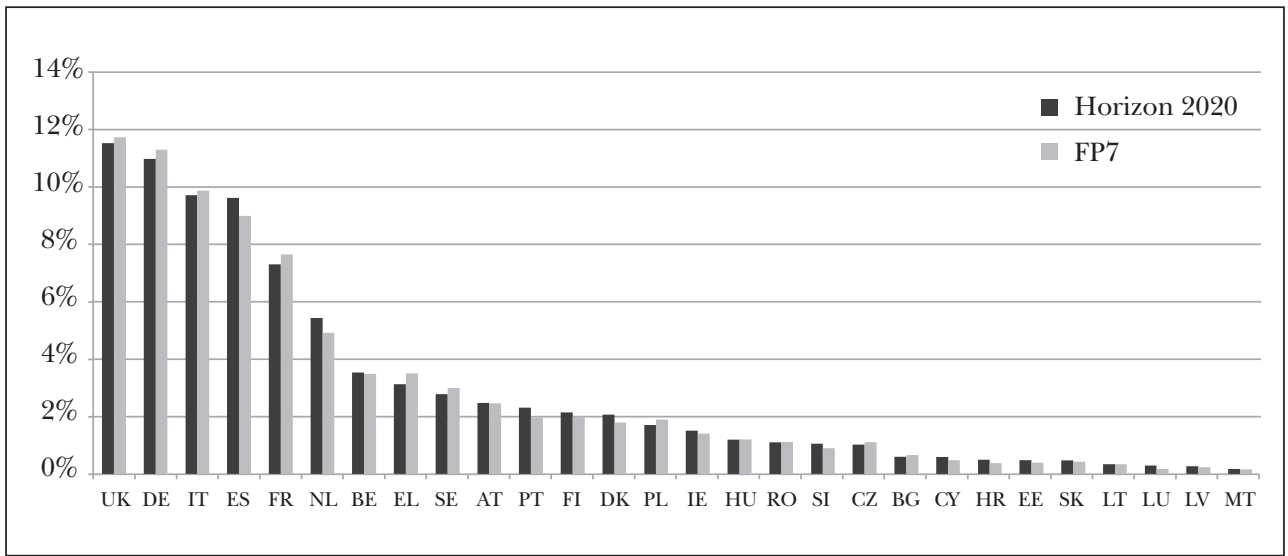

Source: European Commission, 2020, p. 19

contact costs and language use (taking into account the prevalence of English and the process of "Anglicisation" of training programmes). The various institutionalised options (teacher and researcher applications) may improve the process not only by reducing transaction costs, but also by financing other costs. This has triggered increased teacher and researcher mobility, and diversification in the ethnic composition of the staff of HEIs. To quote a good example: in 2017, 12 percent of the academic staff at HEIs in Germany was foreign (Federal Statistical Office, 2020).

Thus it can be said that - due to the general characteristics of competition - the discussed processes may have a positive impact on HEIs in terms of both performance and innovation capacity. At the same time, as competition is also a consequence of natural selection, the above may also result in the fallout and decline of those who perform weaker. In terms of quality, this can be assessed as a positive outcome. However, given the inequalities in the initial conditions of countries and institutions (such as budgetary constraints) and the different roles and specific local functions of different HEIs, local interests are also severely affected by selection, which does not necessarily exclude those of lower quality, and may be conflicted or even harmed. Subsequently, the latter may have adverse social and macroeconomic consequences for the community concerned.

As a specific feature, the EHEA allows students and HEIs to make choices on favourable institutional and transaction-cost terms on a global scale. For Hungarian higher education, this situation obviously means the loss of many outstandingly talented Hungarian students, but at the same time it can attract excellent students from all over EHEA with competitive scholarship schemes in the region. Therefore, in addition to financing schemes, the strategic task should obviously be the concentration of resources on the development of competitive branches and specialisations with comparative advantages in the region. 
József Golovics, Pál Veres: Intensification of Competition in European and Global...

It is also important to emphasise that if competition encourages HEIs to make qualitative progress, and this may also be reflected in the improvement of rankings. Thus, institutions also compete indirectly in rankings. A problem or an unnatural development trajectory can be caused by the fact that some universities aim at direct competition and advancement in rankings alone. As an adverse outcome, rankings do not only act as indicators, but also put a pressure on HEIs to obtain positions available in other competitive fields. Thus, even a small change can trigger a cumulative causal process, a positive feedback mechanism, and as a result, the image created by the rankings may deviate substantially from the genuine performance.

Finally, although reduction in the transaction costs has been discussed through other global processes, participation in the above described areas of international competition can also entail serious (transaction) costs. Entrance to the global and regional space alone requires new expenditures not previously incurred. These may include the costs of international marketing, organising agency relationships responsible for student recruitment, and the multilingualisation of the institution's educational and administrative processes. ${ }^{7}$

\section{Competition in the labour market}

It follows from the above that in addition to lower transaction costs, graduates now also compete internationally for jobs that provide higher wages and better working and social conditions. This is especially true in the EU, where the institutional system is specifically designed to offer more opportunities for the individual, but also provide more competitors. The higher the prestige of an institution, the greater the chances of its graduates, if they can effectively present their competencies, if their country has a sufficiently transparent qualification system and migration management institutions that assume part of the (transaction) costs. Reducing mobility costs for working abroad increases chances in competition, but these costs are still significant for the employee and must be offset by the extra return on migration - typically by higher wages (Golovics, 2019b). In this respect, however, the EU is clearly “promising”, especially for the citizens of the Member States that have acceded since 2004. As shown in Figure 3, there are huge differences in wage levels between the old and new Member States, both in euro and at purchasing power parity. This, in turn, may be a natural trigger for international labour flows, which, at the same time, may result in severe losses for the source country in the event of the brain drain of the most talented students and highest skilled individuals (Golovics, 2019a).

Brain drain can affect higher education not only through the loss of graduates and the public resources spent on their training (Golovics, 2019a), but also directly through the departure of employees. The fact that the employment space has also expanded and employment opportunities abroad have become more transparent and accessible should not be disregarded. Retention of the best staff thus imposes additional costs on institutions. For employees, this means that, in principle, there are significantly different (income and other) benefits available for the same performance. 
Figure 3: Annual net earnings in EU Member States (2019)

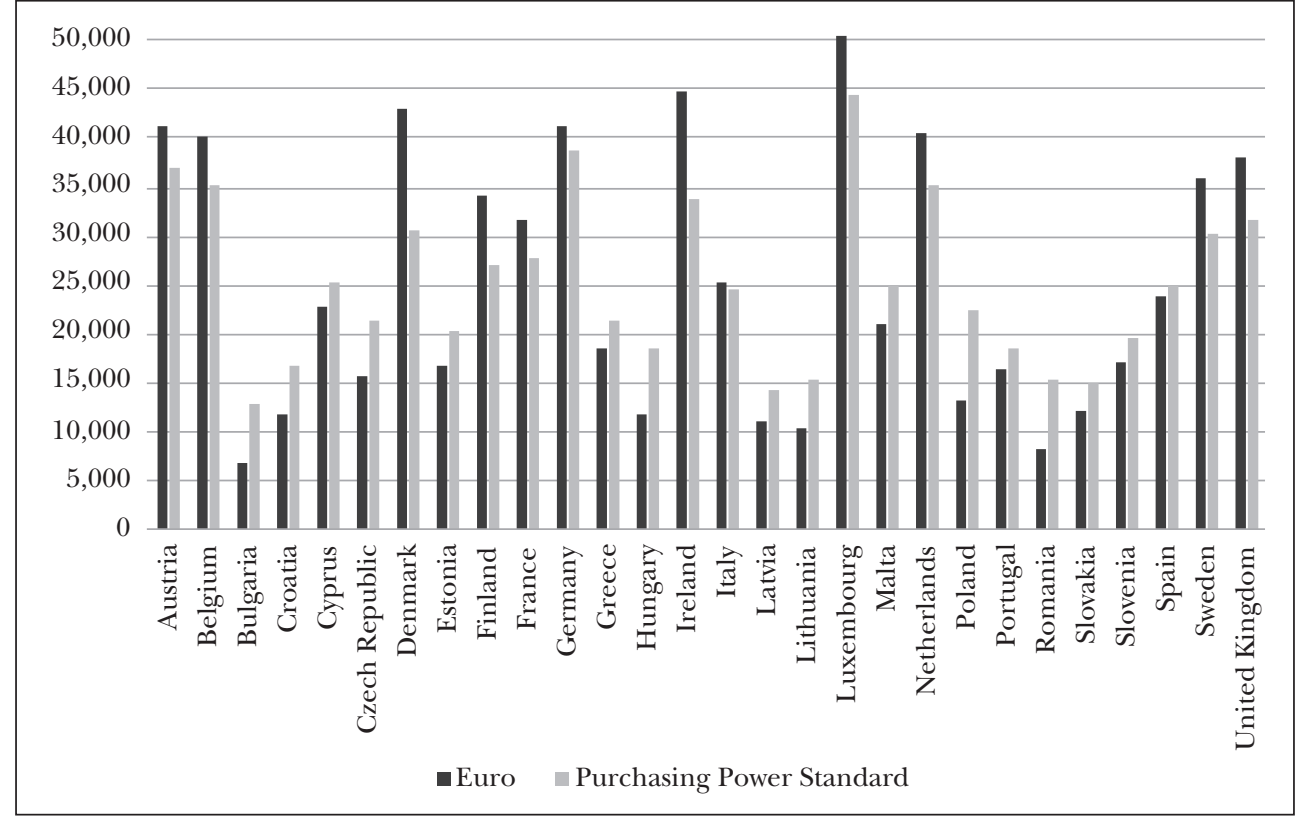

Source: Eurostat, $2020 b$

This may also put HEIs (and frequently entire countries) with lower benefit potential at a permanent disadvantage - either through losing the best employees or by "overpaying them". Although the phenomenon primarily affects the academic staff, the importance of key professionals and managers in the service background cannot be overemphasised. Hungary is still in a phase of convergence in the region (as are the countries of the southern periphery and other former socialist countries). The basis for catching up is competitiveness, and higher education has a strategic role. Consequently, the higher education system of converging countries, such as Hungary, must be made competitive as soon as possible in terms of the quality and adaptability of training and its conditions. However, the retention of talent and the attraction of new talent are insufficient. In order to retain the best graduates and attract young talents from EHEA, it is also necessary to create competitive conditions in the labour market.

Last but not least, it should be mentioned that HEIs have a different, indirect involvement in the development of the labour market. Due to the "quality" of their graduates, they also compete for the employers' recognition. Based on previous experience with graduates, employers can and do have a definite opinion about HEIs and their graduates, up to the point where they can explicitly adhere to graduates from a particular institutional circle. The prestige of a higher education institution provides positive feedback in a specific group of employers, as it also improves the chances in competition. Recognition by employers may be reflected in higher employment rates, 
József Golovics, Pál Veres: Intensification of Competition in European and Global...

better salaries, other working conditions, but also in lasting, conceptual and financial benefits with institutions (joint educational and research projects, scholarships, etc.). The competitiveness of the graduates of an institution in the regional and global space has a number of additional benefits (e.g. alumni), which also improve the opportunities of the institution as a positive feedback.

\section{SUMMARY AND OUTLOOK}

This study reviews the relationship between higher education and globalisation, with focus on the European Higher Education Area. The regional integration of national systems has been significantly facilitated by reduction in transaction costs. Although in some cases globalisation may have led to an increase in the latter, in the process their decline was the predominant cause and effect. This is manifest in higher education in the evolution of general globalisation processes, mostly driven by ICT development, and in the development of global and regional international structures and institutional frameworks. All this had a significant impact on the lives and functioning of the stakeholders of higher education: with the widening of the spectrum caused by globalisation and the parallel reduction in transaction costs, interactions between the actors also entered into a new regional dimension. Through the processes described in the study, competition between the actors has become more frictionless, and it has also become sharper due to the presence of a larger number of stakeholders. The EU, the EQF, national frameworks and the EHEA also provide the most advanced institutional conditionality for interactions - competition and co-operation - globally. And this has an impact on all the stakeholders in higher education, which opens up new opportunities for them, but can also present them with non-negligible challenges. Responses can determine trends and opportunities for future development at the individual, higher education institutional, national and regional levels. It should be emphasised in particular that closing the gap is an additional historical and long-term task for the periphery, i.e. Southern and Central Europe, and higher education has an unavoidable role to play. In line with the findings of Veres (2016), it is emphasised that ensuring freedom and competition in the region is a serious challenge, which involves a risk in conversion, and therefore making higher education competitive should be a priority in national education policies and strategies. With the "softening" of nation-state borders, state entities and sub-state organisations (in this case, universities and colleges) also find themselves in an increasingly uncertain system of regional and global dependence and competition.

Competition is the price paid for freedom. A nation's prosperity in (convergence to) the EU, and more specifically to the EHEA and to the wider global space depends to a large extent on the ability of higher education and the economy to retain and attract talent. The strategic partnership between the national higher education system and the state, the competitiveness of the higher educational system, has a decisive role in this. 
Civic Review · Vol. 16, Special Issue, 2020

\section{Notes}

1 The COVID-19 global virus crisis has demonstrated the potential of ICT to trigger face-to-face encounters (including in education), and the vulnerability of regional and global transactions. As we have seen, such a health crisis can delay transactions, and thus the performance of the entire world economy within a very short time.

2 The Hungarian Qualifications Framework distinguishes 8 levels. The 4 upper levels include higher educational vocational training, bachelor's training, master's training and doctoral $(\mathrm{PhD})$ training. The peculiarity of the Hungarian system is that the learning outcomes are defined in 4 categories: knowledge, ability, attitude, autonomy and responsibility.

3 Although, the framework is described as an institution that reduces transaction costs, it should be mentioned that its establishment and operation also involve transaction costs. The latter may be termed as a political transaction cost (Furubotn and Richter, 2005). It should be emphasized, therefore, that although the existence of qualifications frameworks entails significant cost savings for competing actors, they do not disappear completely, but are passed on to others, as the creation, operation, development and maintenance of institutions represent a significant workload for those working in administration (government or higher education). It is therefore important to have a comprehensive look at transaction costs and to consider how they are shared by stakeholders, especially transaction actors and communities at different levels (social costs).

4 With regard to the decision support institutions, it is also worth mentioning the career tracking and career guidance systems that can already be said to be general in the EHEA.

5 For more information on the types of costs incurred in higher education and cost sharing, see Veres, 2012.

6 Seventh Framework Programme for Research.

7 It cannot be overemphasised that the accounting and measurement of transaction costs is not simple, and its effect also significantly depends on distribution between stakeholders. In the case of a converging country still at a significant competitive disadvantage, the involvement of the state in funding costs is particularly important, in order to relieve the direct participants in the transaction.

\section{REFERENGES}

Crystal, D. (2012): English as a Global Language. Cambridge University Press, Cambridge.

Deli-Gray, Zs.; Árva, L. and Gray, M. (2010). Globalizáció a felsôoktatásban - szervezeti és marketingkövetkezmények [Globalisation in higher education - structural and marketing consequences]. Marketing $\mathcal{E}^{\circ}$ Menedzsment, Vol. 44, No. 3, 4-13.

European Commission (2020): Horizon 2020. First Results. https://ec.europa.eu/programmemes/horizon2020/sites/horizon2020/files/horizon_2020_first_results.pdf (accessed 17 August 2020).

Eurostat (2019a): Foreign Language Learning Statistics. https://ec.europa.eu/eurostat/statistics-explained/ index.php?title=Foreign_language_learning_statistics (accessed 14 January 2020).

Eurostat (2019b): Foreign Language Skills Statistics. https://ec.europa.eu/eurostat/statistics-explained/index.php/Foreign_language_skills_statistics (accessed 14 January 2020).

Eurostat (2020a): Share of Mobile Students from Abroad Enrolled by Education Level, Sex and Country of Origin. http://appsso.eurostat.ec.europa.eu/nui/show.do?dataset=educ_uoe_mobs03\&lang=en (accessed 10 August 2020).

Eurostat (2020b): Annual Net Earnings. https://appsso.eurostat.ec.europa.eu/nui/show.do?dataset=earn_ nt_net\&lang=en (accessed 11 August 2020).

Federal Statistical Office (2020): Foreign Academic Staff, by Type and Size of University, in 2007 and 2017. HIS computations. www.wissenschaftweltoffen.de/wwo2019/wissenschaft-weltoffen-2019_abbildung_d3.xls (accessed 11 August 2020).

Furubotn, E. G. and Richter, R. (2005): Institutions and Economic Theory. The Contribution of the New Institutional Economics. The University of Michigan Press, Ann Arbor, https://doi.org/10.3998/mpub.6715. 


\section{József Golovics, Pál Veres: Intensification of Competition in European and Global...}

Gervai, P. and Trautmann, L. (2014): A felsôoktatás a globalizáció új korszakában [Higher education in the new era of globalisation]. Létünk, Vol. 9, No. 3, 42-65.

Gilpin, R. (2001): Global Political Economy. Understanding the International Economic Order. Princeton University Press, Princeton.

Golovics, J. (2018): Elvándorlás a felsôoktatás szemszögébôl. Helyzetkép és kormányzati válasz [Exodus from the perspective of higher education. State of play ]. In: Kováts, G. and Temesi, J. (eds.): A magyar felsôoktatás egy évtizede, 2008-2017 [A decade in Hungarian higher education, 2008-2017]. BCE NFKK, Budapest, 171-182.

Golovics, J. (2019a): Addressing the EU's East-West Brain Drain: Why a Tax Solution Would Be in Vain. New Perspectives, Vol. 27, No. 2, 63-85, https://doi.org/10.1177/2336825x1902700204.

Golovics, J. (2019b): A nemzetközi migráció mozgatórugói: elmélet és empíria [Motivations of international migration: theory and empiricism]. Demográfia, Vol. 62, No. 1, 95-141, https://doi.org/10.21543/ dem.62.1.3.

Hámori, B. (2013): Új szereplók és magatartásformák az átalakuló tranzakciós térben [New participants and conducts in the transforming transactional space]. Doctoral thesis, Corvinus University of Budapest.

Hrubos, I. (2014): Verseny - értékelés - rangsorok [Competition - evaluation - ranking]. Educatio, Vol. 23, No. 4, 541-549.

Hrubos, I. (2018): Az Európai Felsôoktatási Térség kiépítésének második évtizede [The second decade of building the European Higher Education Area]. In: Kováts, G. and Temesi, J. (eds.): A magyar felsốoktatás egy évtizede, 2008-2017 [A decade in Hungarian higher education, 2008-2017]. Corvinus University of Budapest, 39-45.

Hummels, D. (2007): Transportation Costs and International Trade in the Second Era of Globalisation. Journal of Economic Perspective, Vol. 21, No. 3, 131-154, https://doi.org/10.1257/jep.21.3.131.

North, D. C. (1990): Institutions, Institutional Change and Economic Performance. Cambridge University Press, Cambridge.

Rohonczi, E. (2012): Nemzetköziesedés és versenyképesség a felsôoktatásban [Internationalisation and competitiveness in higher education]. Gazdaság Ẽ Társadalom, Vol. 4, No. 3-4, 52-69.

Székely-Doby, A. (2007): A gazdasági rendszerek és a globalizáció [Economic systems and globalisation]. In: Szabó, K. (ed.): Összehasonlító gazdaságtan [Comparative economics]. Aula, Budapest, 283-310.

Szentes, T. (2002): A világgazdaság az ezredforduló elején [Global economy at the beginning of the new millennium]. In: Blahó, A. (ed.): Világgazdaságtan 2. Globális fejlôdés, gazdaságpolitika [World economics 2. Global development and economic policy]. Aula, Budapest, 23-142.

Temesi, J. (2011): On the International Ranking and Classification of Research Universities. In: Szalai, Z. (ed.): Higher Education in Hungary and the World: Tendencies and Potentialities. Mathias Corvinus Collegium, Budapest.

Vaira, M. (2004): Globalisation and Higher Education Organisational Change: A Framework for Analysis. Higher Education, Vol. 48, No. 4, 483-510, https://doi.org/10.1023/b:high.0000046711.31908.

Veres, P. (2010): A felsốoktatás kihívásai és válaszai az új évezredben [Challenges and responses in higher education in the new millennium]. Iskolakulturra, Vol. 20, No. 5-6, 171-203.

Veres, P. (2012): A költség-haszon elv értelmezhetôsége a hazai felsőoktatás finanszírozásában [Comprehensibility of the cost-benefit principle in Hungarian higher education]. Polgári Szemle, Vol. 8, No. 1-2, 100-122.

Veres, P. (2015): A képesítési keretrendszer lényege és lehetséges hatásai a felsôoktatásban [The essence and possible impacts of the certification framework in higher education]. In: Temesvári, Zs. (ed.): Kandó a tudomány hajóján. XXX. Kandó Konferencia 2014 [Kando on board the ship of science]. Óbuda University, Budapest.

Veres, P. (2016): Kihívások és változások a magyar felsôoktatás rendszerében, különös tekintettel a 2010 utáni idôszakra [Changes and challenges in the Hungarian higher educational system, particularly in the period after 2010]. Polgári Szemle, Vol. 12, No. 1-3, 115-138.

Williamson, O. E. (1985): The Economic Institutions of Capitalism. Firms, Market, Relational Contracting. Free Press, New York. 